\title{
Differend in Toni Morrison's The Bluest Eye
}

\author{
Mehdi Amiri \\ Department of English Language and Literature, Islamic Azad University, E-Campus, Tehran, Iran
}

E-mail: mehdiamiri00@gmail.com

Doi:10.7575/aiac.alls.v.8n.3p.181

Received: $15 / 04 / 2017$

URL: http://dx.doi.org/10.7575/aiac.alls.v.8n.3p.181

Accepted: 28/06/2017

\begin{abstract}
Through the process of passage of man's life, there are some conditions and situations wherein he remains silent and he cannot do anything in the response of others. A postmodern French thinker, Jean-François Lyotard articulates that man is forced to be silent in confronting to some situations and conditions. Lyotard states that man is incapable of representing and expressing his own inner emotions and thoughts in some conditions. This situation of unrepresentability and unanswerability is named differend by Lyotard. Due to Lyotard's differend, through reading Toni Morrison's The Bluest Eye, the reader can notice that there are some conditions in which some characters are unable to represent and state their own feelings and ideas. In this sense, some black people or characters of the novel are surrounded by the conditions that they cannot utter themselves when they face others, especially white people.
\end{abstract}

Keywords: Differend, Silence, Unanswerability, Unrepresentability, Utterance

\section{Introduction}

Looking at man's life, it can be seen that there are some conditions and situations wherein man is unable to represent and utter what is in his mind in order to answer another person or community. Lyotard, a postmodern thinker, takes this condition of man's disability of representing and expressing his inner feelings and thoughts into consideration, and he entitles it "differend". Lyotard signifies that differend discusses the silencing of specific or special differences which cannot exist and live in an easy and natural way with a larger community. As a result of incapability of expressing themselves, they are forced to stay silent. Jean-François Lyotard represents the concept of differend throughout which an individual or a community is being forced into silence while that individual or community needs to talk and express himself or itself against another individual, community, and group. Jae Emerling states:

Lyotard continues this line [metanarrative and minornarrative] of thought, adding an ethical imperative, in The Differend. Here he uses the term "differend" to explain the silencing of particular differences that do not fit within larger conceptual or social totalities. It signifies that someone or something has been denied voice or visibility by the dominant ideological system which deems what is and is not unacceptable. Such radical differences are suppressed because they cannot be subsumed under overarching universal concepts without undermining them. "Differend" means at once dispute, differences, and otherness (alterity) (205).

Through the process of events in Toni Morrison's novel, The Bluest Eye, Breedloves remain silent and cannot express their ideas and themselves. Reading Toni Morrison's The Bluest Eye, the reader finds out some of characters especially Pecola- being raped by her father- unable to defend themselves or herself against the society and situation, therefore, she has been condemned to silence which culminates in differend. Mr. Breedlove (father) tries to express himself by drinking alcohol, fighting his wife, Pauline, and finally raping his daughter, Pecola. His wife, Pauline, cannot present herself by words, and she remains silent; therefore, she tries to show herself by working for a white family. The most remarkable person, being kept silent, is Pecola, being raped by her father and wishing to have blue eyes in order to get rid of the harsh situation of her life. Because of being unable to express themselves lingually and defend themselves against white society of America, they are condemned to stay silent, and those unpleasant events happen to them.

\section{Differend in Theory}

The term, being introduced by Lyotard as differend, states the difference between two or more groups or persons and marginalizes and silences one of the two sides called differend. According to Lyotard, there is an injustice because someone cannot represent himself and his truth of his words, as a result, law or judge accuses him so that he is condemned to silence. In book entitled The Routledge Dictionary of Literary Terms (2006), Peter Childs and Roger Fowler point out:

The differend, for Lyotard, is an injustice suffered by those whose signifying system is silenced by established representations of 'reality'; as such, it is part of an ethical programme in which 'the unpresentable'- that which is silenced in every discursive event- is witnessed and activated as an element within the process of judgement (57). 
Lyotard applies the term, differend, to elucidate a moment or situation in which there are differences between two groups. In this situation, one side has superiority over the other side. The inferior side is sentenced to silence as a result of being rejected and withheld by dominant ideological and ruling system to present itself and its ideas or words. In other words, the inferior side is silent, since it cannot adjust to standards and ideologies of the superior society. The difference is suppressed because the minor side and its criteria cannot be undermined by universal and total concepts and standards of the major society. Moreover, such a difference and conflict cannot be resolved because of lack of rules of justice in order to put an end to the argument and demand equal rights and justice to both sides of conflict. Lyotard, in his book, The Differend Phrases in Dispute (1988), defines as:

As distinguished from a litigation, a differend would be a case of conflict, between (at least) two parties, that cannot be resolved for lack of a rule of judgment applicable to both of the arguments. One side's legitimacy does not imply the other's lack of legitimacy. However, applying a single rule of judgment to both in order to settle their differend as though it were merely a litigation would wrong (at least) one of them (and both of them if neither side admits this rule) (xi).

In addition, Lyotard depicts differend as impotency and incapability of one side of conflict to represent, state, and attest its words and claim that it is true and in the right. He asserts that one side of the argument expresses itself and represents its word; however, the other side remains silent. Lyotard articulates:

The differend is signaled by this inability to prove. The one who lodges a complaint is heard, but the one who is a victim, and who is perhaps the same one, is reduces to silence (Lyotard 1988: 10).

In the eye of Lyotard, differend is a situation in which the instability of language results in unpresentability and inexpressibility of some phrases and words. In this sense, differend is situation wherein words cannot be represented and language cannot produce phrases. Hence, the side, unable to represent itself, is silenced and accused, and it is suffered as an injustice which cannot confirmed its claim, so it is considered a wrong. Lyotard utters:

The differend is the unstable state and instant of language wherein something which must be able to be put into phrases cannot yet be. This state includes silence, which is a negative phrase, but it also calls upon phrases which are in principle possible. (Lyotard 1988:13).

In line with, Simon Malpas, in the book entitled Jean-François Lyotard, illustrates differend as the moment of silence wherein lack of words and phrases language brings about unpresentability and inexpressibility of language. It means one side, in lack of representing and saying its words and ideas, is sentenced to silence, and it is considered a wrong which do not have right to be in justice side.

The differend is a moment of silence, a stutter in the flow of language, where the right words will not come. It marks a point of suffering where an injustice cannot find a space to make itself heard where an injury is silenced and becomes a wrong (Malpas 2003:61).

In this sense, the idea of differend comes with its subdivision, injustice. Referring to a situation of differend wherein one side is condemned to be silent and have no right to represent itself, the side is deemed wrong and injustice. Although, judge supposes that he is right and just and judges truly, Lyotard states that justice is done when a lot of sides are respected and treated the same and in an equal way and given right to represent their words and claims. Nevertheless, injustice, he presents, occurs when one side is sentenced to be silent. In his book entitled Just Gaming (1985), in series of dialogues between Lyotard and Jean- Loup Thébaud, Lyotard announces:

Absolute injustice would occur if...the possibility of continuing to play the game of the just were excluded. That is unjust. Not the opposite of the just, but that which prohibits that the question of the just and the unjust be, and remain, raised. Thus, obviously, all terror, annihilation, massacre, etc., or their threat, are by definition, unjust. But moreover, any decision that takes away, or in which it happens that one takes away, from one's partner in a current pragmatics, the possibility of playing or replaying a pragmatics of obligation (67).

In brief, injustice occurs when one side or person is not allowed to present and state whether by killing it or by silencing to be heard. However, justice occurs when all individuals and sides are respected and treated equally.

Once more, the characteristics of postmodernism are noticeable and clear in Lyotard's idea of differend and justice. It designates and copes with plurality of postmodernism. As Lyotard, one of the prominent postmodernists declares postmodern era is a period when all communities and individuals and their own standards are respected, and no one has superiority over the other. He conveys the idea of plurality by expressing his opinion about differend and justice. 
Regarding Lyotard's theory about the concept of differend, one of the critical moments in Cholly's life, being viewed through the concept of differend, is his first sexual relation with a girl. Having been watched by two white men, Cholly had sex with a girl. They forced him to continue while they were watching him.

When he was still very young, Cholly had been surprised in some bushes by two white men while he was newly but earnestly engaged in eliciting sexual pleasure from a little country girl... "Go on," they said. "Go on and finish. And, nigger, make it good." The flashlight did not move. For some reason Cholly had not hated the white men; he hated, despised, the girl (Morrison 31).

Cholly remained silent while two white men were shining a flashlight on and watching him. He could not even utter a word to defend himself and fight against them physically. He could not react to them. He did what they ordered because he felt weakness. He was so weak that he was condemned to silence confronting the two white men, and he should obey their command. He was oppressed but he did not strive to defend and represent himself against the white men.

The scene or event which can be discussed due to Lyotard's concept of differend is Pecola's being harassed by a circle of black boys. They taught her for her black skin, ugliness, and naked father. They surround her and make fun of her because of her ugliness and black skin and her family. However, Pecola remains silent, and she does not fight and react to them. She cannot even express a word to represent her against them. "Pecola edged around the circle crying. She had dropped her notebook and covered her eyes with her hands" (Morrison 50). Pecola is forced and condemned to silence. She cannot utter and represent herself and her own characteristics of beauty against the black boys. She is not able to state her inside feelings into the word and phrase and she stays silent.

Through the process of reading Toni Morrison's The Bluest Eye, Cholly's and his father's meeting is one of the noteworthy events which can be discussed and studied based on Lyotard's theory about the concept of differend. When Cholly met his father, he strived to introduce himself as his father's son- Samson Fuller's son. However, he could not express the words and even he could not say his mother's name because he did not know it.

"No, sir, I'm..." Cholly blinked. He could not remember his mother's name. Had he ever known it? what could he say? Whose boy was he? He couldn't say, "I'm your boy." That sounded disrespectful (Morrison 122).

After Cholly said Samson Fuller that he was his son, Samson refused to accept his words and behaved him angrily and cursed Cholly. He could not say any words in reply to his angry words and mood, and he remained silent. Cholly was forced to silence because of Samson's cruel treatment. This was the event and moment in which Cholly was condemned to silence and he could not represent his words against Samson Fuller.

Cholly was a long time picking his foot up from the ground. He was trying to back up and walk away. Only with extreme effort could he get the first muscle to cooperate. When it did, he walked back up the alley, out of its shade, toward the blazing light of the street (Morrison 123).

While Pecola were being raped by her father, she did not react to him, and she did not say even a word or phrase to him in order to complain. "The rigidness of her shocked body, the silence of her stunned throat, was better than Pauline's easy laughter has been" (Morrison 128). She was not able to express a word and represent herself, and she was condemned to silence. Moreover, after being raped, Pecola lay on the floor kitchen under a heavy quilt. Morrison states, "So when the child regained consciousness, she was lying on the kitchen floor under a heavy quilt, trying to connect the pain between her legs with the face of her mother looming over her" (129). She could not connect to her mother and declare what had happened to her. Again, she remained silent.

\section{Conclusion}

This article copes with some of the events in which some of the characters are silent and unable to express any words in order to represent themselves. Lyotard calls this moment of silence differend. Lyotard defines differend as "the unstable state of language wherein something which must be able to put into phrases cannot yet be" (Lyotard 1988:13). In her novel The Bluest Eye, Morrison articulates some of the events in which the characters stay silent and they do not even utter a word. For instance, when young black boys are annoying Pecola and hitting her, she does not defend herself lingually or physically. It is the situation wherein she is condemned to silence, while it is a very necessary time when she should speak an defend herself.

The other noticeable event in The Bluest Eye, being discussed in the light of Lyotard's differend, is one in which Cholly have been watched by two white men while he was having sex with a girl. The two white men forced him to continue while they were watching him. Cholly obeyed them without reacting against them lingually or physically. It was the moment in which Cholly was sentenced and forced to silence. He could not even say a word in order to defend himself.

Regarding to the events of The Bluest Eye in which some characters remain silent, Toni Morrison conveys there are some of the situations in which a person cannot represent himself or herself. She states that such a kind of person is 
condemned to silence because he or she cannot utter a word nor do something against the others. Because of lack of words and phrases to be expressed, the person is sentenced to silence and even to guilt. In this regard, Toni Morrison expands it from a person to community, especially black communities, which are not able to represent their own standards and ideas facing the white dominant societies. Therefore, they are condemned to silence, and they should obey what the dominant persons and societies tell and command.

\section{References}

Child, Peter, and Roger Fowler. The Routledge Dictionary of Literary Terms. London and New York: Routledge, 2006.

Emerling, Jae. Theory for Art History. London and New York: Routledge, 2005.

Lyotard, Jean-François. Just Gaming. Trans. Wlad Godzich. Mineapolis: University of Minnesota Press, 1985.

---. The Differend: Phrases in Dispute. Trans. George Van Den Abbeele. Mineapolis: University of Minnesota Press, 1988.

Malpas, Simon. Jean-François Lyotard. London and New York: Routledge, 2003.

Morrison, Toni. The Bluest Eye. London: Vintage, 1999. 